\title{
FACILITATED WORKSHOPS AND THE FOCUS GROUP AS A WAY TO GAIN OPINIONS AND FORMATTING A NEW PRODUCT WITH THE Z GENERATION
}

\author{
KAMILA SŁUPIŃSKA \\ University of Szczecin, Faculty of Management and Economics of Services, POLAND \\ kamila.slupinska@wzieu.pl
}

RECEIVED
ACCEPTED
JEL
CLASSIFICATION

KEYWORDS

ABSTRACT
18 January 2018
2 September 2018

$\mathrm{M} 31, \mathrm{M} 39, \mathrm{O} 2$

Facilitated Workshops, focus studies, qualitative research, generation Z, decision making process, communication

The aim of the article was to show how to obtain opinions, as well as to shape a new product for the generation of $Z$. The article focuses on the use of selected qualitative research, in which one can learn about what young people are directed by. Through their direct involvement, one can observe what aspects play a special role for them. In the first part of the article, the author presents the characteristics of the $\mathrm{Z}$ generation and selected research forms. Next, the results of focused group interviews and the results of the supported workshops were presented, which were an integral part of the study. The aim of the study was to get to know the way of thinking of the $\mathrm{Z}$ generation, the determinants that guide it in the framework of purchasing decisions and the identification of forms of marketing communication that they identify. This goal has been achieved by involving the participants into the role of, on the one hand, producers of a given product, on the other, researchers who have to determine what customers like them are paying attention to. As a result of focus research, information about elements that capture the attention of the young generation while shopping was obtained. As part of the workshop, a simplified proposal for a communication campaign for the selected product was developed. The combination of both methods enabled the active involvement of all participants and the observation of what particular elements draw attention of young consumers in their decision-making process. Due to volume restrictions of publication the results of the research were focused on the methodological aspect, ie the results of the use of selected research forms, rather than on the results of the research topic. The results and conclusions from the adopted theme constitute a separate article.

\section{Introduction}

Nowadays, getting to know the opinion about a given product seems to be not so difficult to achieve. Depending on the desire to deepen a given issue, you can apply quantitative research - if you are interested in, e.g., how a wide range of recipients will find a given product, or qualitative research, when, for example, we want to know the reasons for purchasing decisions. Is the current classical use of research methods sufficient for the younger generations 
of $Z$ and what if we want to shape a new product for them? So how to get information from the younger generation, which also participates in the process of purchasing decisions, so as to know their actual opinions and behavior. The author in the article focused on a qualitative research approach. She presented the results of research, in which both focused group interviews and facilitated workshops were used.

\section{Means of communication of generation $Z$}

The manner of communication and the values we follow illustrate, to a large extent, belonging to a particular generation. This determines particular habits, attitudes, expectations, behaviors and susceptibility to various arguments or motivational stimuli. The ability to recognize these differences allows you to effectively reach with a specific offer.

Generation Z, also known as generation C, refers to people born in the 90 s. The social life of the generation $Z$ is largely carried out on the Internet. The Internet is most natural environment in which they were raised, but it does not mean that the real world does not play a significant role for them. This is confirmed by interviews with representatives of this generation conducted by Natalie Hatalska (2015). In their statements, the young generation of $Z$ indicated that they prefer much more direct contact with their peers than through digital media.

This generation reveals accelerated development of children, mainly under the influence of the media and advertising of the so-called KGOY phenomenon (kids getting older younger). Instead of traditional toys, they prefer dedicated versions of electronic gadgets, cosmetics or fashionable clothing. In addition, brand awareness is also picked up early (Aniszewska, 2015, p. 3). As shown by the results of the study conducted by the YouGov global portal (YouGov: Children..., 2018), teens want to co-decide on shopping. As many as $48 \%$ of teenagers between 11 and 16 regularly get pocket money, which they want to spend according to their own taste (Olczyk, 2017).

Advertisers are aware of the potential of the youngest. They know that the young generation recognizes and at the same time exerts a great influence on the parent who makes purchases, hence they value the possibility of making them unofficial brand ambassadors (Olczyk, 2017).

Although the generation is much more resistant to advertising messages, they pay attention to them. However, as Duncan Southgate of global brand director in the media \& digital department of Kantar Millward Brown: "Members of this Generation grew up in a world where many things are available on demand, and the choice is almost unlimited. This is what shapes their expectations towards advertising. They are much more attracted to the advertisements that enable them to create or shape the course of events together "(Pokolenie Z..., 2017). Based on the results of the "AdReaction: Engaging Gen X, Y and Z" study, conclusions have been drawn that the generation $Z$ draws more attention to the creative approach to changes. They prefer advertising, which can be affected by them. They want to co-create a story or see what happens when they make a decision. They are better oriented towards brands that give them the opportunity to influence the development of events (31\% in the Z generation versus $25 \%$ in the $Y$ generation), they can choose an option ( $28 \%$ vs. $25 \%$ ) or make a decision (27\% vs. $22 \%)$ ("AdReaction: Engaging Gen X, Y and Z").

\section{Characteristics of the applied research methods}

Qualitative research methods have a special application in research related to the introduction of new products to the market, especially at the product development stage. Feedback from potential customers at an early stage of creation helps avoid costly mistakes and increases the chance for market success. The concept that can be 
presented to the respondents often requires many explanations of the person conducting the research, hence the quantitative research does not apply. The reactions of potential buyers are also difficult to predict, which makes it impossible to create a questionnaire with relevant questions (Maison, 2007, p. 9).

The main goal of qualitative research is a broader understanding of reality and the studied area (Maison, 2007, p. 9). Qualitative research is primarily a careful observation and analysis what the participants are not allways aware of. The methods of qualitative research include focused group interviews commonly called focus studies. The history of development of this method is presented by numerous foreign authors (including Stewart, Shamdasani, Rook, 2007; Savin-Baden, Howell-Major, 2013; Carey, Asbury, 2016). First publications describing and presenting the use of group interviews dates back to 1913 (Strong, 1913, pp. 393-395), despite the fact that they were not yet called group interviews. Subsequent authors who used this research method in their projects include Poffenberge (1925), Bogardus (1926), Moreno (1931), Laxarsfcld (1934, 1937). Also during World War II, focus studies found their application (Morgan, Krueger, 1993). In addition, the development of focus groups is associated with the research programs of P. Lazarsfeld, R. Merton and their collaborators (Merton, Fiske, Kendall, 1990). It was at this time that the focus was first held and called the focussed interview.

As we can observe, this method was popular mainly in the area of psychological and sociological social research. Only after the war did they find widespread use in marketing research, thanks to which in the $80 \mathrm{~s}$ of the twentieth century, they re-experienced scientific flourishing (Lisek-Młynarska, 2013, p. 14).

The focus group methodology is common to many disciplines, but its application can be varied. According to the definition proposed by David Morgan (1997), it is a research technique in which the researcher collects the information necessary for his/her purposes through cooperation and interaction with a group of participants. In addition, focus groups rely on meeting people who do not know each other, but who have common experiences or are well familiar with an issue. They are best suited to environments or groups in which its representatives are willing, open to communication and have knowledge of a given topic, and the facilitator of the group has the appropriate skills (Carey, Asbury, 2016, p. 15). The scenario is a characteristic component of the focus study. It is treated as an "interview plan, defining the main issues that should be discussed in the interview, and determining the time that the moderator should devote to discussing these issues" (Maison, 2007, p. 16).

Analyzing literature from 20-30 years ago, many of the characteristic focus features presented there are currently not required. Modifications apply to aspects such as the duration of the interview, the number of participants, the place where the interview was conducted or the freedom to conduct the interview. The changes are not the result of research assumptions, but the experiences of moderators who, while conducting the research, sometimes do not strictly follow the rules, obtain more information than when they conduct it in a traditional way (Maison, 2001, pp. 16-17).

Focus studies also use projection methods that further stimulate the group's work. These methods are a vast source of knowledge about the motives of behavior, goals, aspirations and ways of perceiving the surrounding world of the individual. The basic feature of projection methods are ambiguous, unstructured stimuli that force the individual to act creatively, to speak in accordance with his/her own thoughts and feelings. In the projection method, the analyzed material may include verbal stimuli, drawings, photographs, play techniques, etc. (Kranc, 2018).

Facilitated workshops are intense meetings during which participants work together on tasks related to the development of a specific product (Schalken, Brinkkemper, Vliet, 2004, pp. 135-144). As a research approach, it is an open choice of methods that allow us to interact, and improve and moderate our project research in time [Ørngreen, Levinsen, 2017, pp. 71-81). 
In 1948, Osborn described for the first time the workshops as a method of creative group problem solving (CPS) known as "brainstorming". As we can read in the Danish dictionary (2016), the use of the term "Workshop" became popular in the early sixties, when Osborn's idea and related social issues spread on a large scale. While Osborn's CPS approach developed, a wide range of various workshop formats appeared that were specific to a given industry or discipline (Ørngreen, Levinsen, 2017, pp. 70-81).

Workshops are specifically designed to fulfil a pre-defined, though not predictable, purpose. They shoud promoted genuine participation. The participants are expected to actively participate and influence the workshop's direction. The group is small to give everyone personal the chance to be heard. By the workshop participants expect an outcome like the generation of new insights, suggestions, (re)designs of a product, or innovation (Ørngreen, Levinsen, 2017, pp. 70-81).

During the workshop, participants work on developing a consensus of ideas and work out joint solutions. The facilitator is expected to keep track of whether the goals set at the beginning have been met. This saves time and ensures that nothing is left out.

As research and conclusions from the workshops conducted as part of the research by the research team of Rikke Ørngreen and Karin Levinsen Research center for VidEO, ILD-lab, Department of Learning and Philosofy, Aalborg University, Copenhagen, Denmark from Research center for VidEO, ILD-lab, Department of Learning and Philosofy, Aalborg University, Copenhagen, Denmark (Ørngreen, Levinsen, 2017, pp. 70-81) demonstrate: "the workshops play a special role in identifying, articulating and exploring poorly defined or fuzzy challenges in research areas." In addition, the workshop method helps to reveal unrecognized or unacknowledged dead spots to participants. The authors presented the advantages and difficulties of conducting workshops, pointing to the wide possibilities they provide.

The author, referring to the advantages and methods of obtaining and engaging the respondents by means of both research methods, decided to apply them together during the research conducted with representatives of the $\mathrm{Z}$ generation. According to the author, this is the best way to get complete feedback from the group. It is a generation that expects the world to "revolve around them and for them". Personalization, the ability to choose your own way in every situation, and above all individual treatment and respect for the opinions, are ways to win the hearts of the youngest generation of consumers (Bakalarska, 2016). Both of these methods can provide them. On the one hand, giving the opportunity to listen - during focus tests, on the other hand - in support workshops, as a result of which a product ideal for them will be created.

\section{Methodology and results}

Before conducting the research, the moderator made a series of participant and non-participant observations among the younger generation of $Z$, in order to properly shape the study, in terms of the manner of communication, time, place and form of its implementation. The tests took place in August and September 2017 in the focus group at the Faculty of Management and Economics of Services at the University of Szczecin.

The group of people participating in the first study included pupils from the primary school who were invited to participate in the workshop. The second group was represented by junior high school students who participated in the workshops as part of the West Pomeranian Science Festival. All participants of the study were informed about the purpose of the place where they are staying. Both groups were divided into smaller groups of 6-8 people. Both studied groups, except for focus interviews, participated in assisted workshops. 
For the purposes of the research, an unstructured, free scenario was prepared, containing thematic areas under which the moderator held discussions with the participants. It should be noted that observation of the group in terms of the degree of concentration and commitment was particularly important. Generation Z rather quickly gets bored, which is manifested by a reduced level of communication or expressing views that are only meant to "show up in the group." At that time, the statements are no longer one's real views. With this in mind, it was assumed that the duration of the study should not exceed one hour. The results of the research were focused on the methodological aspect, rather than on the results of the research topic. The results and conclusions from the adopted theme constitute a separate article.

In each of the studied groups, the aim of the study was to recognize the preferences of the selected product, i.e. chocolate. Participants were asked to share their opinion about it - as regards the taste, price, quality preferences, etc. The projection method was used and the participants were to take on the role of the Chocolate Factory owners who want to introduce a new product to the market. In this way, the participants of the study were to reflect and answer the question, what elements would draw attention and what would be the preferences of people from their generation. As part of both groups and its individual subgroups, group leaders stimulated other people to ask questions. Sometimes the other participants agreed with their opinion, but they also loudly objected when they had a different view. In the focus part in both cases, although one of the subgroups in the initial phase of the discussion, stimulation of the moderator to express their opinions more openly was required. In addition, some people, even those encouraged by the moderator, were concerned about public speaking or tried to divert attention from themselves through jokes. During the course of the conversation, especially in the part concerning communication, and especially advertising, all people in the groups have become active, which shows that despite claims that ads are not watched or are not interesting for them, their reactions denied it. As part of the speech, one could additionally observe active non-verbal communication that allows to receive confirmation of the views expressed. In individual groups, it was also possible to identify wizards - originators who sometimes proposed nonstandard solutions. After the end of the focus section, the group eagerly began work on the implementation of the workshop project. It was noticeable that people who were previously less active, became more open and willing to act. As a result of the supported workshops, the previously appearing statements from the focus studies were additionally verified. During the process of creation, some of the elements that in the first stage of the research played a significant role for them, when implemented, e.g., an advertising spot, they went to the background.

The conducted focus studies supported by workshops allowed to identify the strengths and weaknesses of the initiated research method. In addition, they have also made it possible to evaluate the effectiveness of their use among the $Z$ generation for the needs of obtaining information and designing a new product. On their basis, it can be stated that active, engaging forms of obtaining information from the $Z$ generation fulfill their functions, however it would be worth having both verbal and non-verbal forms. Thanks to this, each participant will be able to present their views, even those less open to group discussions.

\section{Conclusions}

On the basis of conducted research and observations, it can be stated that using non-standardized methods of qualitative research, it is possible to obtain a wide range of verbal and non-verbal information from Generation $Z$. The author notices the need to make this type of modification in the methods of research of the young generation. 
Active forms of research in this group allow for a deeper understanding of their needs and expectations. By considering their way of expressing themselves, communication needs and willingness to co-create, businesses can get much more than just information. As we can see, companies are increasingly taking action, adopting forms of communication with young participants of the world of social media, through their direct involvement. Therefore, according to the author, the research area should also consider such a possibility.

\section{References}

Aniszewska, G. (2015). Zmiany pokoleniowe a decyzje i wybory konsumenckie. Marketing i Rynek, 1, 3-6.

Bakalarska, J. (2016). Pokolenie Y vs. Pokolenie Z - co powinni o nich wiedzieć marketerzy, cz. I. Retrieved from: https://marketerplus. $\mathrm{pl} /$ teksty/cykle/pokolenie-y-vs-pokolenie-o-nich-wiedziec-marketerzy-cz.

Bogardus, E.S. (1926). The Group Interview. Journal of Applied Sociology, 10, 372-382.

Carey, M.A., Asbury, J.E. (2016). Focus Group Research. Routledge.

Hatalska, N. (2015). Generacja Z - pokolenie które zmieni nasz świat. Retrieved from: http://hatalska.com/2015/01/22/generacja-zpokolenie-ktore-zmieni-nasz-swiat.

Kranc, K. (2018). Znaczenie metod projekcyjnych. Retrieved from: www.edukacja.edux.pl/p-15750-znaczenie-metod-projekcyjnych. php.

Laxarsfcld, P.F. (1934). The Psychological Aspects of Market Research. Harvard Business Review, 3 (October), 54-71.

Laxarsfcld, P.F. (1937). The Use of Detailed Interviews in Market Research. Journal of Marketing, 2 (July), 3-8.

Lisek-Michalska, J. (2013). Badania fokusowe. Problemy metodologiczne i etyczne. Łódź: Wydawnictwo Uniwersytetu Łódzkiego.

Maison, D. (2001). Zogniskowane wywiady grupowe. Jakościowa metoda badań marketingowych. Warszawa: Wydawnictwo Naukowe PWN.

Maison, D. (2007). Jakościowe metody badań marketingowych. In: A. Noga-Bogomilski, D. Maison (eds.), Badania marketingowe: od teorii do praktyki (pp. 91-109). Gdańsk: GWP.

Moreno, J.L. (1931). The Eirst Book on Group Psychotherapy. New York: Beacon House.

Morgan, D.L. (1997). Focus Groups as Qualitative Research. SAGE Focus Editions.

Morgan, D.L., Krueger, R.A. (1993). When to Use Focus Groups and Why In: Successful Focus Groups: Advancing the State of the Art. SAGE Focus Editions.

Olczyk, D. (2018). Dzieciocentryzm, czyli jak dzieci wpływają na decyzje zakupowe rodziców? Retrieved from: www.nowymarketing. $\mathrm{pl} / \mathrm{a} / 16178$,dzieciocentryzm-czyli-jak-dzieci-wplywaja-na-decyzje-zakupowe-rodzicow.

Ørngreen, R., Levinsen, K.T. (2017). Workshops as a Research Methodology. Electronic Journal of ELearning, 15 (1), 70-81.

Poffenberger, A.T (1925). Psychology in Advertising. Chicago, IL: A.W. Shaw.

Pokolenie Z rośnie i jest gotowe na wyzwania - badanie Kantar Millward Brow (2017). Retrieved from: https://marketingprzykawie.pl/ espresso/pokolenie-z-rosnie-i-jest-gotowe-na-wyzwania-badanie-kantar-millward-brown.

Savin-Baden, M., Howell-Major, C.(2013). Qualitative Research: The essential guide to theory and practice. Oxford: Routledge.

Schalken, J., Brinkkemper, S., van Vliet, H. (2004). Assessing the effects of facilitated workshops in requirements engineering. Proceedings of 8th IEEE International Conference on Empirical Assessment in Software Engineering (EASE2004), 135-144.

Stewart, D.W., Shamdasani, P.N., Rook, D.W, (2007). Focus Groups: Theory and Practice. SAGE Publications.

Strong, E.K., Jr. (1913). Psychological Methods as Applied to Advertising. Journal of Educational Psychology, 4, 393-395.

YouGov. Children make savvy shoppers have refined pester today (2018). Retrieved from: yougov.com/news/2015/06/11/children-makesavvy-shoppers-have-refined-pester-p.

Cite this anticle as: Słupińska, K. (2018). Facilitated workshops and the focus group as a way to gain opinions and formatting a new product with the Z generation. European Journal of Service Management, 3 (27/2), 389-394. DOI: 10.18276/ejsm.2018.27/2-47. 